\title{
Break Even Point Analysis as a Tool for Profit and Sales Planning on Otak-Otak Bandeng Kang Wahab SME
}

\author{
Nisfatur Rizki ${ }^{1}, 2^{\text {nd }}$ Agus Sukoco S.T. MM $^{2}$ \\ Narotama University Indonesia \\ rizkinisfatur30051995@gmail.com
}

\begin{abstract}
This study aims to determine break-even point and margin of safety and how to plan profits and sales by using Break Even Point Analysis on Otak-Otak Kang Wahab SME. The method used in this study is qualitative descriptive with a case study research approach, by conducting direct interviews with the owner. Analysis have been carried out using Break Even Point Analysis. The data being analyzed in this study are production and non-production reports, product prices, sales volumes and costs. The results show that the sales of SME product which have been analyzed through Break Even Point have break-even point after it reaches 7 months 3 days, with revenue of 1.161.996,000 IDR and selling of 25.689 units. Margin of Safety is known to be $21 \%$. In this case, the SME don't include asset investments in the form of business places, because they use their own residence, so the cost isn't considered.

Keywords: Break even point, Profit planning, Margin of safety, Contribution Margin.
\end{abstract}

\section{INTRODUCTION}

In economy of Indonesia, there are ups and downs in every sale, raw material price and demand from the customer which will have influence on a business such as in determining the price and volume of production. The amount of costs in the production process will determine the selling price of the product itself, while the selling price will affect the amount of profit and ultimately will determine how much profit is generated. Profit can be generated if income has exceeded the total costs incurred. In this case, profit planning is very necessary in achieving profit in the continuity of a business.

Analysis is needed in profit planning, sales volume, selling prices and costs. One of the technical analysis that can be used is a break even point analysis, which is a point where a business does not earn a profit or does not suffer a loss, or profit is equal to zero or the total revenue equals the total cost. In this study, the object of the research is Otak-Otak Bandeng Kang Wahab SME.

In carrying out a business, there are various external and internal constraints. External constraints are like the ups and downs of product demand and raw material supply. In a dry season, the fish pond will dry up resulting in reduced supply of milkfish from a supplier so they have to find additional suppliers in order to be able to satisfy the demand. Internal constraint is from the side of workers, taking a leave at the wrong time such as when product demand increases or the SME Owner have not carried out an analysis to analyze the achievement of profits and product selling. SME owner had the desire to expand their business but did not have the courage to take further steps. One way to overcome this is through financial records.

Financial records are very necessary to get information on financial condition of SME over a couple years and also compare it every month therefore SME owner can determine some options and then make a decision for sustainability of their business. The use of Break Even Point analysis will be very useful as a basis for business operational planning to achieve certain profits as consideration to determine the selling price, and also can describe the minimum number of product selling required so that the business does not experience losses.

In this case, the results of various previous studies in the form of findings and theories can be used as a basis or reference and supporting data that are relevant to the problems related to this research.

The first research was conducted by Makmur [1] entitled Analysis of production costs and breakeven business of making small ginger juice. The results show that the business of Zahra instant ginger extract is feasible (profitable) because the revenue is greater than the expenditure used in the business and also in terms of Break Even Point production and price of instant ginger juice Zahra deserves to continue and profit can be generated because it exceeds Break Even Point production and prices.

Putri [2] entitled Break Even Point Analysis as a profit planning tool (Case Study of Batik Djoyokoesomo SME in Blitar). The study shows that there are differences in achievement of break even 
and quantity points each year, but for each year it shows that the sales volume carried out by the Batik Djoyokoesomo SME is good and always breaks even which means that they are able to achieve profits every year.

Lestari [3] Analysis of Break Even Point as a basis for planning profit and sales (Case study on rambak cracker business UD Wahyu Abadi Tulungagung). The results of the study show that in 2011 UD Wahyu Abadi had made sales above the Break Even Point level. Whereas for the profit target and Margin Of Safety the values targeted for 2012 and 2013 were obtained.

Wijana, Triadi \& Kholiq [4] entitled Break Even Point Application on bread making case study: Roti (Rotiku Rotimu) SME in Babakan Village. The results show that the "Roti" SME had reached Break Even Point in the 4th month so that it could be said that it was worthy of being operated.

Choirunnila [5] Analysis of Break Even Point as a profit planning tool for tahu baxo products (case study on Tahu Baxo Ms. Pudji SME in Ungaran). The results show that during 2014, which was taken as a sample for research on Tahu Baxo SME in producing boiled tahu baxo and fried tahu baxo, break-even point has been reached. In other words, the tahu baxo Ms. Pudji SME is able to earn profit and it increases very well.

Alnasser, Shaban \& Zubi [6] entitled The Effect of Break-Even Point in planning, controlling and decision making in the industrial Jordanian Companies. The results show that most Jordanian industrial companies use break even point analysis in planning and control and decision making. And there is a statistically significant relationship between the use of break even point analysis and successful planning, control and decision making in Jordanian industry companies.

Ndaliman \& Bala [7] entitled Practical limitations of break even theory. The results of the study reveal the following practical reality related to the theory of break even. The first is that semi-variable costs do exist among cost components and must be considered for proper estimation of fixed costs and variable costs. Second, sales revenue and total costs are not always linear as usually assumed in theory. Third, two or more break events may exist for certain industries depending on a number of factors.

\section{METHODOLOGY}

The methodology applied in this study is descriptive qualitative with a case study research approach. The analysis used is Break Even Point Analysis technique. Data sources are secondary data such as production, non-production reports, product prices, sales volume and costs of Otak-Otak Bandeng Kang Wahab's SME in 2018.

The steps to analyze data in this study include:

1. Gather historical data in the form of profiles and history of SME, sales data, product costs and selling prices from SME of Otak-Otak Bandeng Kang Wahab.

2. Divide the costs into variable costs and fixed costs

3. Perform contribution margin calculations, break even point, margin of safety, and profit and sales planning.

4. Analyze profit then make assumptions of maximum profit obtained.

5. Make conclusions.

Calculation of Break Even Point formula:

On the basis of the IDR :

$$
\text { Break even point }=\frac{\text { Fixed Costs }}{1-\frac{\text { Variable Costs }}{\text { Sales }}}
$$

On the basis of the unit :

$$
\text { Break even point }=\frac{\text { Fixed Costs }}{\text { Selling price per unit }- \text { Variable cost per unit }}
$$


Calculation of Contribution margin :

$$
\text { Margin Kontribusi }=\text { Sales }- \text { Variable costs }
$$

Contribution Margin (unit) = Selling price per unit - Variable cost per unit

$$
\text { Contribution Margin Ratio }=\frac{\text { Contribution Margin }}{\text { Sales }}
$$

Calculation Margin of Safety :

$$
\text { Margin of safety } \%=\frac{\text { Actual total sales }- \text { Break even sales }}{\text { Actual total sales }}
$$

\section{RESULT AND DISCUSSION}

Here are overall cost data tables of Otak-Otak Bandeng Kang Wahab SME during 2018:

Otak-Otak Bandeng Kang Wahab Kang SME Overall Cost Data in 2018.

Table 1. The overall cost of Otak-Otak Bandeng Kang Wahab SME

\begin{tabular}{lr}
\hline Costs & Total \\
\hline Cost of goods sold & \\
Raw material costs & 454.770 .000 \\
Direct labor costs & 107.750 .000 \\
Factory overhead & 46.449 .000 \\
Auxiliary material costs & 334.228 .125 \\
Cost of consumables & 158.925 .000 \\
Total Cost of goods sold & 1.102 .122 .125 \\
Operating costs & \\
Cost of gas & 11.084 .000 \\
Electricity cost & 15.400 .000 \\
Cost of Water & 2.400 .000 \\
Cost of gasoline & 15.805 .000 \\
Cost of telephone & 660.000 \\
Maintenance costs & 1.100 .000 \\
Cost of depreciation & 40.050 .000 \\
Salary expense & 204.000 .000 \\
Total Operating costs & 290.499 .000 \\
Total cost of overall & 1.392 .621 .125 \\
\hline
\end{tabular}

Based on the table 1, it shows that the total cost is 1.392.621.125 IDR, which was obtained from the sum of the total cost of product selling and total of operational costs.

In the Break Even Point analysis the separation of costs into fixed costs and variable costs is carried out as follows : 
Table 2. The separation of fixed costs and variable costs.

\begin{tabular}{llr}
\hline Costs & Variable costs & Fixed costs \\
\hline Cost of goods sold & & \\
Raw material cost & 454.770 .000 & \\
Direct labor costs & 107.750 .000 & \\
Factory overhead & 46.449 .000 & \\
Auxiliary material costs & 334.228 .125 & \\
Cost of consumables & 158.925 .000 & \\
Operating costs & & \\
Cost of gas & & 11.084 .000 \\
Electricity cost & & 15.400 .000 \\
Cost of water & & 2.400 .000 \\
Cost of gasoline & & 15.805 .000 \\
Cost of telephone & & 660.000 \\
Maintenance costs & & 1.100 .000 \\
Cost of depreciation & & 40.050 .000 \\
Salary Expense & 1.102 .122 .125 & 204.000 .000 \\
Total Operating cost & & 290.499 .000 \\
& & 1.392 .621 .125 \\
\hline
\end{tabular}

Based on the table 2, a fixed cost of 290.499.000 IDR and variable cost is 1.102.122.125 IDR. So, the total cost is 1.392.621.125 IDR.

Here are data on sales of Otak-Otak Bandeng Kang Wahab SME during 2018 :

Table 3. Data on sales of Otak-Otak Bandeng Kang Wahab SME

\begin{tabular}{cccc}
\hline Period & Sales & Selling price & Total \\
\hline 1 year & 32.712 & $45.000 \mathrm{IDR}$ & $1.472 .040 .000 \mathrm{IDR}$ \\
\hline
\end{tabular}

Based on the table 3, shows that total product sales during 2018 were 32.712 products and generated sales of 1.472.040.000 IDR.

Here are the income statement of the products in 2018 :

Table 4. Income statement of Otak-Otak Bandeng Kang Wahab SME. Otak-Otak Bandeng Kang Wahab SME Income Statement

\begin{tabular}{lrr}
\multicolumn{3}{c}{2018} \\
\hline Sales & & 1.472 .040 .000 \\
Cost of goods sold & 454.770 .000 & \\
Raw material costs & 107.750 .000 & \\
Direct labor costs & 46.449 .000 & \\
Factory Overhead & 334.228 .125 & \\
Auxiliary material costs & 158.925 .000 & \\
Cost of consumables & & 1.102 .122 .125 \\
Total Cost of goods sold & & 369.917 .875 \\
Gross profit & & \\
Operating costs & 11.084 .000 & \\
Cost of Gas & 15.400 .000 & \\
Electricity cost & 2.400 .000 & \\
Cost of water & 15.805 .000 & \\
Cost of gasoline & 660.000 & \\
Cost of telephone & 1.100 .000 & \\
Maintenance costs & 40.050 .000 & \\
Cost of depreciation & 204.000 .000 & \\
Salary expense & & 290.499 .000 \\
Total Operating cost & & 79.418 .875 \\
Profit before tax & & 397.094 \\
Tax (0.5\%) & & 79.021 .781 \\
\hline Net profit & & \\
\hline
\end{tabular}

Based on the table 4, that sales received on the SME in 2018 amounted to 1.472.040.000 IDR. The total cost of product selling is 1.102.122.125 IDR. The Grofit profit is 369.917.875 IDR obtained from 
difference in sales and the total Cost of Sales. The total operational cost is 290.499.000 IDR. Pre-tax profit is the difference from gross profit and total operating cost. The SME tax of 0,5\% generates 397.094 IDR. So, the total of the net profit is 79.021.781 IDR.

From the data on costs and sales that have been obtained, it can be used to calculate the profit report plan by calculating the contribution margin using the contribution margin formula.

\subsection{Calculation of Contribution Margin}

Table 5. Calculation of contribution margins during 2018.

\begin{tabular}{lrr}
\hline & \multicolumn{1}{c}{ Total } & Per unit \\
\hline Sales & 1.472 .040 .000 & 45.000 \\
Variable costs & 1.102 .122 .125 & 33.692 \\
\cline { 2 - 3 } Contribution margin & 369.917 .875 & 11.308 \\
Fixed costs & 290.499 .000 & \\
\cline { 2 - 3 } Net profit & 79.418 .875 & \\
\hline
\end{tabular}

Calculations made by formula (5), which is the distribution of contribution margins with sales, then the ratio of contribution margins obtained is equal to 0,25 or $25 \%$. In table 5 , the contribution margin is generated through formula (3) which is 369.917.875 IDR. And by using the formula (4), which is the difference between the selling price per unit and the variable cost per unit, the contribution margin per unit produced is 11.308 units. So, after the cost classification, it can be seen that the contribution margins that occur in Otak-Otak Bandeng Kang Wahab SME in 2018 have a contribution margin ratio of 25\% with sales of 1.472.040.000 IDR. Contribution margin can be expected is 369.917.875 IDR or 33.692 per unit, so the net profit generated is 79.418.875 IDR.

\subsection{Calculation of Break Even Point}

From the calculation using the formula (1) the resulting Break even is 1.161.996.000 IDR. From the formula (2) the Break Even Point generated is 25.689 units. So, the break-even point of SMEs is reached after 7 month and 3 days, having the product selling of 25.689 unit and total sales of 1.161.996.000 IDR, at that time the SME hasn't generated a profit though.

\subsection{Calculation of Margin of Safety}

Calculations is carried out through formula (6), which is the difference of actual sales and break-even sales divided by actual total sales, then the Margin of Safety produced is equal to 0.21 or $21 \%$. So, it can be seen that the maximum amount of decline that can occur until the break-even point is $21 \%$.

\section{CONCLUSION}

Based on the results of research and analysis of data on Otak-Otak Bandeng Kang Wahab SME, it can be concluded as follows:

1. Calculation of contribution margin in Otak-Otak Bandeng product is 369,917,875 IDR and 33,692 units, with a contribution margin ratio of $25 \%$ and with net income of 79.418.875 IDR. It shows that Otak-Otak Bandeng Kang Wahab SME has the ability to cover fixed costs and operating costs. Breakeven point has been reached within 7 month 3 days.

2. Break Even Point Calculation of Otak-Otak Bandeng Kang Wahab SME products shows that Break Even Point will be achieved when sales reach 1.161.996.000 IDR, 25,689 Units of the products are sold. It shows that the product of Otak-Otak Bandeng Kang Wahab SME have reached sales above Break Even Point.

3. The Margin of safety on Otak-Otak Bandeng Kang Wahab SME in 2018 is $21 \%$. it shows that SME will suffer a loss if $21 \%$ of decline is occured.

\section{REFERENCES}

[1] Makmur, “Analisis Biaya Produksi Dan Titik Impas Usaha Kecil Pembuatan Sari Jahe Instan,” vol. 10, no. 1, pp. 57-65, 2016.

[2] R. L. Putri, “Analisis Break Even Point Sebagai Alat Bantu Perencanaan Laba (Studi Kasus UMKM Batik Djoyokoesomo Blitar)," vol. 4, pp. 41-54, 2017.

[3] Y. D. Lestari, “Analisis Break Even Point (BEP) Sebagai Dasar Perencanaan Laba Dan Penjualan (Studi 
Kasus pada Usaha Kerupuk Rambak UD Wahyu Abadi Tulungagung),” 2012.

[4] M. Wijana, A. Triadi, and M. Kholiq, "Aplikasi Break Even Point Pada Pembuatan Roti Studi Kasus: Usaha Kecil Menengah (UKM) Roti (Rotiku Rotimu) Desa Babakan,” Din. Tek. Mesin, vol. 5, no. 1, pp. 2088-88, 2015.

[5] U. Choirunnila, “Analisis Break Even Point Sebagai Alat Bantu Perencanaan Laba Pada Produk Tahu Baxo (Studi Kasus Pada Umkm Tahu Baxo Ibu Pudji Di Ungaran),” 2016.

[6] D. N. Alnasser, D. O. S. Shaban, and D. Z. A.- Zubi, "The Effect of Using Break-Even-Point in Planning, Controlling, and Decision Making in the Industrial Jordanian Companies," Int. J. Acad. Res. Bus. Soc. Sci., vol. 4, no. 5, pp. 626-636, 2014.

[7] M. B. Ndaliman and K. C. Bala, "Practical limitations of break-even theory," Technology, vol. 11, no. 1, pp. 58-61, 2007. 